\title{
A HONRA OBJETIVA DAS PESSOAS JURÍDICAS E O DIREITO DE REPOSTA EM FACE DE NOTÍCIAS DE SUSPEITA DE ENVOLVIMENTO EM CASOS DE CORRUPÇÃO
}

\author{
Marcus Vinícius de Souza e Souza ${ }^{1}$ \\ Maria Vital da Rocha ${ }^{2}$
}

\section{Resumo:}

Foi regulamentado no Brasil o direito de resposta. Recentemente, também tornou-se recorrente a divulgação de notícias jornalísticas acerca do envolvimento de pessoas jurídicas em atos de corrupção. Tais notícias são, geralmente, publicadas antes do trânsito em julgado de sentenças judiciais condenatórias, de modo que retratam suspeitas da prática de atos ilícitos. Tais notícias repercutem sobre os direitos da personalidade dos personagens envolvidos, surtindo influência sobre sua honra objetiva. O intuito é verificar se a divulgação de notícias da suspeita do envolvimento de pessoas jurídicas em casos de corrupção enseja direito de resposta em razão da violação de sua honra objetiva.

Palavras-chave: Direito de Resposta; Corrupção; Notícias Jornalísticas; Direitos da Personalidade; Honra Objetiva.

\section{THE OBJECTIVE HONOR OF LEGAL ENTITIES AND ITS RIGHT OF REPLY REGARDING NEWS REPORTING SUSPICIONS OF ITS INVOLVEMENT IN CASES OF CORRUPTION}

\begin{abstract}
:
Recently, the right of reply was regulated by law. Recently it also became recurrent the divulgation of journalistic news regarding the involvement of legal entities in acts of corruption. Such news are most of the times, reported before there as a final decision, reason why it only report suspicions. Such news have effects over legal entities' personality rights since it has rebounds over these legal entities' objective honor. The purpose of this paper is to analyze if news reporting suspicions of involvement of legal entities in corruption cases enables the right of answer due to violation of objective honor.
\end{abstract}

Keywords: Right of reply; Corruption; Journalistic news; Personality Rights; Objective Honor.

\section{INTRODUÇÃO}

\footnotetext{
${ }^{1}$ Mestrando em Direito do Programa de Pós-Graduação em Direito da Universidade Federal do Ceará.

${ }^{2}$ Professora da Universidade Federal do Ceará e do Centro Universitário 7 de Setembro. Procuradora Federal. Doutora em Direito pela Universidade de São Paulo.
} 
Em 2015, com a edição da Lei Federal n ${ }^{\circ}$ 13.188/2015, que dispõe acerca de tal direito, passou o ordenamento jurídico pátrio a contar com regulamentação para o exercício do direito de resposta, concedendo-se tal direito a pessoas físicas e jurídicas que tenham seus direitos ofendidos pela divulgação de notícia em veículo de comunicação social.

Dentre os direitos defendidos, o presente trabalho destaca o direito à honra objetiva das pessoas jurídicas, que consiste no juízo ético e de valor que a sociedade faz a seu respeito. Apesar de haver ainda alguma discussão doutrinária acerca do tema, o posicionamento majoritário da doutrina e do Poder Judiciário é que, resguardados determinados limites, as pessoas jurídicas são titulares de direitos da personalidade.

Recentemente, com a divulgação da existência de vários procedimentos investigativos e judiciais, é crescente a quantidade de notícias que reportam suspeitas de envolvimento, dentre outros, de pessoas jurídicas de direito privado em esquemas de corrupção. Parte-se, portanto, do pressuposto de que existem notícias publicadas com estas características.

Não é relevante ao presente estudo analisar se determinada gestão governamental ou determinada pessoa jurídica de direito privado cometeram fatos ilícitos ou não. Sendo divulgadas suspeitas de envolvimento de sociedades empresárias em tais práticas antes de sua efetiva comprovação, que se dá pelo trânsito em julgado de sentença condenatória, haverá que se discutir acerca de seu direito de resposta.

Assim, o objetivo deste trabalho consiste em analisar se a publicação de notificas retratando suspeitas de envolvimento de pessoas jurídicas de direito privado em casos de corrupção ofende seu direito à honra objetiva e se desta ofensa decorre a possibilidade de exercício de direito de resposta, nos termos da Lei Federal no 13.188/2015.

\section{A CORRUPÇÃO E A DETERIORAÇÃO DAS RELAÇÕES SOCIAIS}

O ato de corrupção praticado no âmbito do Poder Público pode ser definido como aquele que implica em prejuízo ao patrimônio público em razão da subversão de normas, formais ou implícitas, de gestão governamental (GLAESER; GOLDIN, 2004, p. 7). O prejuízo ao patrimônio público pode consistir tanto em perdas econômicas, decorrentes do pagamento superfaturado de preços, como na contratação de serviços ou produtos de 
qualidade inferior mediante o pagamento do mesmo valor que seria pago pelos de qualidade superior.

Por sua vez, a subversão a normas de gestão governamental consiste na inobservância de preceitos legais e éticos que venham a facilitar ou possibilitar tais prejuízos. Este ilícito modo de agir pode ou não resultar em obtenção de vantagem indevida pela autoridade pública que tenha cometido o ilícito (BARROS FILHOS; PRAÇA, 2014, p. 73).

O presente trabalho volta-se aos atos de corrupção que envolvam os entes de direito público, e que implicam, portanto, em prejuízo ao patrimônio público, conjuntamente com pessoas jurídicas de direito privado. Sobre o tema, Guilherme de Souza Nucci (2015, p. 3) afirma que a corrupção "caracteriza-se, nitidamente, pela negociata, pelo pacto escuso, pelo acordo ilícito, pela depravação moral, gerando, muitas vezes, estragos ao Estado".

Vê-se, com isso, que além dos evidentes prejuízos econômicos decorrentes da corrupção, há uma outra consequência: a depravação moral das pessoas envolvidas, o que, quando tais casos vêm à tona, possui consequências graves sobre sua honra objetiva, que, conforme será desenvolvido adiante, consiste no juízo que a sociedade faz acerca da ética e da lisura da atuação de determinado sujeito.

O próprio termo "corrupção" é formado pela junção dos elementos "co", que indica a presença de 2 (dois) ou mais agentes na relação, e "rupção". Este último termo indica o rompimento de laços sociais entre os corruptores e aqueles que foram prejudicados pelos ilícitos cometidos. No caso, a sociedade (BARROS FILHO; PRAÇA, 2014, p. 24).

Esta "rupção" existe mesmo nos casos em que a sociedade não tome conhecimento do ato praticado em seu desfavor: os sujeitos envolvidos no ato de corrupção, apesar de continuar a ostentar imagem de lisura de sua atuação, passam a estar inseridos em sociedade cujas regras, éticas e legais, de convivência social não respeitam. Tem-se, com isso, sujeito que apenas simula adequar-se à sociedade em que se insere, mas que apenas utiliza-se de seu patrimônio para locupletamento próprio.

Não é incomum que, ao se deparar com um caso de corrupção, a sociedade tome conhecimento de que tal prática não se esgotou em uma operação isolada, mas que perpetrou-se durante determinado período. A circularidade destas práticas denota o 
rompimento dos laços sociais entre os corruptos e a sociedade, que se vê a mercê da ganância e da dissimulação de agentes públicos e privados agindo para benefício próprio e em seu desfavor.

Se o rompimento de laços sociais decorre naturalmente da mera prática de atos de corrupção, a divulgação de tais atos à sociedade, ludibriada, acentua-o. Ao tomar conhecimento de que determinado sujeito, seja pessoa física ou jurídica, distorceu e violou estruturas legais cujo intuito é promover o desenvolvimento da sociedade, e que o fez com o mero objetivo de obter vantagens próprias, a reação natural é o alijamento social de tal sujeito.

É certo que o alijamento social não implica em exclusão de determinado sujeito do convívio social, mas sim na formulação de um (ou alteração acerca do) juízo de valor que a sociedade tem acerca do sujeito envolvido no ato que a lesou.

As regras de gestão pública determinam a utilização de bens públicos à prestação de serviços ou ao fornecimento de produtos por um justo preço. Portanto, ao ver tais regras violadas em prol de interesses privados, a sociedade vê-se violada em seu âmago, pois o esforço social para a formação do patrimônio público foi recompensada pela usurpação de tais bens por sujeitos também inseridos nesta mesma sociedade.

Segundo Modesto Carvalhosa, ao contrário do que ocorre em delitos semelhantes praticados por pessoas físicas, quando o agente envolvido é uma pessoa jurídica não convém, por impossível, aferir-se o "elemento subjetivo de intenção, por se tratar de elemento psicológico que inexiste no caso" (CARVALHOSA, 2015, p. 72).

É neste sentido que dispõe o art. $2^{\circ}$ da Lei Federal $n^{\circ} 12.846 / 2013$ - Lei Anticorrupção, que regulamenta a responsabilização de pessoas jurídicas pela prática de atos de corrupção realizados em seu favor. Tal lei foi sancionada pela Presidência da República em $1^{\circ}$ de agosto de 2013, época em que havia grande pressão social para a adoção de medidas que evitassem e punissem a prática de atos de corrupção.

A Lei Anticorrupção teve o papel de instituir penalidades a pessoas jurídicas beneficiadas por atos de corrupção. O contexto de sua edição e a gravidade das penalidades aplicáveis, que podem chegar, por exemplo, a aplicação de multa de $20 \%$ (vinte por cento) do 
faturamento bruto da sociedade e em sua dissolução, demonstram o clamor social por medidas que punam efetivamente a prática de atos de corrupção.

Conclui-se que a divulgação do envolvimento de pessoas jurídicas em corrupção provoca-lhes consequências, não só jurídicas, mas sociais, o que ocorre mesmo que se tenha apenas uma "suspeita" de envolvimento. Cumpre, portanto, analisar os direitos de personalidade da pessoa jurídica, em especial o direito à honra objetiva, o que se passa a fazer.

\section{OS DIREITOS DA PERSONALIDADE}

O conceito de direitos da personalidade surgiu associado às pessoas físicas, consistindo naqueles direitos inerentes à pessoa humana, tanto "tomada em si mesma" como em suas "projeções na sociedade", estando previstos no ordenamento jurídico com o intuito de defender "valores inatos ao homem, como a vida, a higidez física, a intimidade, a honra, a intelectualidade e outros tanto" (BITTAR, 1995, p. 1).

O surgimento dos direitos da personalidade decorreu de uma mudança de paradigma que teve como expoente superado o chamado período dos "códigos oitocentescos", em que a legislação cível somente era capaz de garantir a igualdade formal, e não material. Após a Revolução Francesa, consagrou-se a divisão do Direito entre Público e Privado, havendo quase inexistente comunicação entre eles (DONEDA, 2003, p. 39).

Enquanto no Direito Público o cidadão era resguardado contra desmandos do Estado mediante direitos erigidos em cartas constitucionais e declarações diversas, na seara privada não havia tais mecanismos, prevalecendo a autonomia privada (DONEDA, 2003, p. 39). Com isso, o indivíduo, muitas vezes, via-se sem direito a qualquer proteção estatal caso tivesse seus violados por terceiros.

Somente no transcorrer do século $\mathrm{XX}$, em especial com a entrada em vigor do Código Civil Alemão, em 1900, e da Constituição de Weimar, em 1919, passou-se a prezar pela tutela dos direitos pessoais dos indivíduos, com sua efetivação mesmo em relações privadas. Tendo como inspiração o desejo de prevenir novas barbaridades como as cometidas durante a Segunda Guerra Mundial, foi celebrada entre as nações a Declaração dos Direitos 
do Homem, de 1948, documento essencial para que o ser humano passasse a ser protegido em decorrência de sua própria natureza (PEREIRA, 2010, p. 203).

Dentre os direitos protegidos, inserem-se os direitos da personalidade, que decorrem da própria condição humana, aderindo aos seres humanos meramente em razão de sua natureza. Esta classe de direitos recebeu especial atenção do legislador brasileiro, que lhes dedicou todo um capítulo do Código Civil, delimitado entre os artigos 11 e 21. Sua previsão como categoria própria de direitos pelo legislador que erigiu a legislação que entrou em vigor a partir de 2002 demonstra uma mudança de paradigmas no Direito Brasileiro, que passou a ter como valor máximo a proteção à pessoa.

A "personalidade", "objeto" de proteção dos direitos da personalidade, refere-se ao indivíduo em toda a sua complexidade, podendo ser definida como "o conjunto de poderes, direitos, faculdades, prerrogativas em exercício, ou em prática" (RIZZARDO, 2007, p. 248), exprimindo a "aptidão genérica para adquirir direitos e contrair deveres" (PEREIRA, 2010, p. 181). Por possuir caráter dinâmico, a personalidade não é protegida em si própria, mas em suas manifestações perante a sociedade.

Segundo Miguel Reale, coordenador do então projeto do atual Código Civil, ao erigir tais direitos, especialmente com a atenção que lhes dispensou, o legislador teve por intuito salvaguardar o indivíduo sob seus diversos aspectos. Como a matéria dos direitos da personalidade possui conteúdo eminentemente ético, eis que protege o indivíduo em sua essência mediante o reconhecimento de direitos inerentes à pessoa humana, os direitos da personalidade foram erigidos mediante "poucas normas dotadas de rigor e clareza, cujos objetivos permitirão os naturais desenvolvimento da doutrina e da jurisprudência" (REALE, 2013, p. 65 apud GONÇALVES, 2013, p. 55).

E é justamente isto que a doutrina pátria tem feito: desenvolver o tema de modo a otimizar a proteção dispensada aos indivíduos. A doutrina trata a diferenciação dos direitos da personalidade em relação aos demais direitos de maneiras diversas. Caio Mário, por exemplo, ensina que os direitos da personalidade destoam daqueles que são economicamente apreciáveis, eis que decorrem aqueles de "um ideal de justiça, sobreposto à expressão caprichosa de um legislador eventual" (PEREIRA, 2010, p. 202). 
Partindo do mesmo pressuposto quanto à importância dos direitos da personalidade e perpassando caminho assemelhado, Arnaldo Rizzardo defende que a distinção entre os direitos de personalidade e os demais direitos dos indivíduos é que aqueles são inerentes aos seus titulares, sendo deles indissociáveis. O mesmo não ocorre, por exemplo, com o direito ao crédito e à propriedade, caracterizados por sua vinculação a institutos diversos da personalidade do indivíduo (RIZZARDO, 2007, p. 151).

A doutrina defende que o indivíduo é um ser único e conta com direitos básicos que o individualizam, como o nome, a liberdade física e intelectual, a honra, a imagem etc, todos direitos inerentes à condição humana. Assim, os direitos da personalidade são essenciais "à plena existência humana, à sua dignidade, ao respeito, à posição nas relações com o Estado e com os bens, à finalidade última que move todas as instituições, eis que tudo deve ter como meta maior o ser humano" (RIZZARDO, 2007, p. 151).

De toda forma, o que se defende é o estado da pessoa enquanto tal, que, segundo Clóvis Beviláqua, consiste em "seu modo particular de existir", correspondente a uma "situação jurídica resultante de certas qualidades inerentes à pessoa" (BEVILÁQUA, 1908, p. 92). Assim, o indivíduo é protegido em tudo aquilo que lhe compõe e em toda a sua existência social.

De acordo com lição de Joyceane Bezerra (2008, p. 191), apesar de os direitos da personalidade pressuporem a existência de uma personalidade a que aderir, a qual inicia-se, por definição legal, a partir do nascimento com vida, tal concepção normativista não é a que melhor defende os indivíduos. Isto ocorre por que mesmo os embriões anteriormente ao nascimento merecem proteção jurídica, haja vista a dignidade da pessoa humana, não sendo aceitável que um indivíduo já nasça tendo contra si prejuízos a sua personalidade.

Orlando Gomes ensina que os direitos da personalidade abrangem "os direitos personalíssimos e os direitos essenciais ao desenvolvimento da pessoa humana", cujo objetivo é a salvaguarda da "dignidade da pessoa humana, preservando-a dos atentados que pode sofrer por parte de outros indivíduos" (GOMES, 1996, p. 130).

Os direitos da personalidade, portanto, tem por objetivo maior resguardar a dignidade da pessoa humana, que, segundo Maria Vital da Rocha e Leonardo José Peixoto Leal, "envolve a tutela da integridade física e psíquica do homem", reservando-se ao 
indivíduo uma esfera livre para desenvolver-se em toda a sua complexidade (ROCHA; LEAL, p. 6).

\section{A POSSIBILIDADE DE EXTENSÃO DOS DIREITOS DA PERSONALIDADE ÀS PESSOAS JURÍDICAS DE DIREITO PRIVADO}

Conforme exposto, os direitos da personalidade passaram a ser implementados nos ordenamentos jurídicos como corolário do reconhecimento da necessidade de proteção mais efetiva aos indivíduos, consagrando-se a dignidade da pessoa humana e alçando-se o homem ao topo do ordenamento jurídico. Mais recentemente, passou-se a discutir a possibilidade de estender tais direitos às pessoas jurídicas, especialmente as de direito privado, discussão esta inclusive decorrente do próprio Código Civil, cujo art. 52 determina-lhes a aplicação, "no que couber", dos direitos da personalidade.

As pessoas jurídicas consistem na unidade de patrimônio e pessoas naturais para a consecução de um objetivo a que o ordenamento jurídico atribui a possibilidade de ser sujeito de deveres e direitos (MONTEIRO, 2003, p. 121). Segundo Arnaldo Rizzardo (2007, p. 248), a "natureza humana leva à conjugação de forças das pessoas para a realização das atividades comuns da vida", o que é possibilitado pela organização de esforços e recursos, que pode se dar pela criação de uma "unidade orgânica", ou seja, de uma pessoa jurídica.

A evolução doutrinária acerca da natureza da pessoa jurídica, que perpassou, por exemplo, pela noção de que sua personalidade não passava de ficção real e, mais recentemente, pelo entendimento de que tal personalidade na verdade residiria nas pessoas físicas associadas, descambou na hoje comumente aceita teoria da personalidade real.

As pessoas jurídicas, criadas que são para atuar na consecução de determinados objetivos, são dotadas de capacidade e personalidade próprias, sendo titulares de seus próprios direitos e obrigações. Em razão disto, contam com existência legal própria e autônoma, devendo seus direitos e deveres ser objeto de regulamentação também autônoma das incidentes sobre as pessoas físicas que as compõem.

Não obstante, este conceito não implica em uma "personalização antropomórfica" das pessoas jurídicas (PEREIRA, 2010, p. 266). O ordenamento jurídico dispensa-lhes tratamento diverso do concedido às pessoas físicas, adaptado ao caso concreto. 
É o que ocorre, por exemplo, no que concerne aos direitos da personalidade, limitando o art. 52 do Código Civil sua incidência às pessoas jurídicas "no que couber".

Caio Mário assevera que há três requisitos caracterizadores de uma pessoa jurídica: “a vontade humana criadora, a observância das condições legais de sua formação e a liceidade de seus propósitos". Após sua constituição (desde que observados os requisitos legais de registro), a pessoa jurídica passa a ter personalidade jurídica autônoma da de seus criadores e integrantes (PEREIRA, 2010, p. 256). A aquisição de uma personalidade própria, inclusive, não é uma faculdade na constituição de uma pessoa jurídica, mas uma necessidade: por não se confundir, em absoluto, com as pessoas físicas que a integram, a pessoa jurídica necessita existir autonomamente no mundo jurídico, respondendo por suas próprias obrigações e gozando de seus próprios direitos (RIZZARDO, 2007, p. 249).

Antes, entretanto, é necessário que haja uma "expressão volitiva especificamente dirigida”, ou seja, a constituição de uma pessoa jurídica depende de uma manifestação de vontade das pessoas físicas que pretendem cria-la. Portanto, as pessoas jurídicas têm "sua gênese na vontade humana" (PEREIRA, 2010, p. 256).

Assim sendo, as pessoas jurídicas são unidades orgânicas formadas pela comunhão de pessoas e bens, cuja constituição decorre de um ato volitivo de indivíduos que pretendem associar-se para a consecução de um objetivo e que possui existência jurídica autônoma, sendo, pois, dotada de personalidade jurídica própria.

Sendo sujeitos de direito, cumpre passar a discutir o seguinte ponto: seriam os direitos da personalidade aplicáveis às pessoas jurídicas? Apesar de haver disposição legal expressa, porém limitadora, que permite a aplicação destes direitos "no que couber" às pessoas jurídicas, há ainda embate doutrinário acerca do tema.

O Código Civil Brasileiro determina, em seu art. 52, que os da personalidade aplicam-se, "no que couber" às pessoas jurídicas. Não obstante, parte da doutrina critica bastante tal disposição, alegando que a pessoa jurídica não foi considerada no "processo histórico formado dos direitos da personalidade", não podendo, pois, usufruir de tais direitos (DONEDA, 2003, P. 54). 
Decorrendo a instituição da proteção dos direitos da personalidade da valoração do indivíduo e da proteção de seus direitos, em nada importaria o fato de que as pessoas jurídicas também contam com personalidade jurídica própria. Segundo esta corrente, o fato de as pessoas jurídicas representarem, em última instância, vontades e anseios de indivíduos, estes sim detentores de direitos da personalidade, tornam-nas merecedoras de proteção jurídica sob regime próprio, a qual, em determinadas situações, pode assemelhar-se a direitos da personalidade.

Por exemplo, a proteção ao nome das pessoas jurídicas não decorreria da necessidade de proteção do indivíduo perante a sociedade, mas de regra comercial que veda a concorrência desleal. Da mesma forma, ao determinar-se que os segredos industriais devem ser protegidos, não estaria o legislador resguardando o direito à intimidade, mas sim interesses econômicos também relacionados a posições vantajosas de mercado.

Assim, a proteção jurídica às pessoas jurídica teria sempre caráter econômico, intuito de resguardar interesses patrimoniais, e não de preservar a personalidade, ou seja, a individualidade de um sujeito em toda a sua complexidade, contra violações, do que decorre a conclusão de que não se lhes aplica a tutela própria de direitos da personalidade.

A “extensão apriorística” dos direitos de personalidade às pessoas jurídica implicaria em deturpação do intuito humanístico destes direitos, comprometendo inclusive a "tábua axiológica constitucional" (DONEDA, 2003, P. 54). Portanto, os direitos da personalidade, que caberiam aos seres humanos "naturalmente" em razão simplesmente de sua natureza humana, não se aplicariam às pessoas jurídicas. Não obstante, este não é o posicionamento que prevalece.

Realmente, o regime jurídico aplicável às pessoas jurídicas é diverso do que se aplica aos seres humanos, pois suas próprias naturezas são diversas. Este fato, inclusive, é reconhecido pelo próprio Código Civil Brasileiro, cujo já mencionado art. 52 limita às pessoas jurídicas a aplicação de direitos da personalidade apenas ao "que couber".

O próprio legislador, de forma, é verdade, incipiente, teve a cautela de ressalvar que há direitos da personalidade que não se aplicam às pessoas jurídicas. ${ }^{3}$ Neste

\footnotetext{
${ }^{3}$ Há variada gama de direitos que, por natureza, não cabe às pessoas jurídicas. É o caso, por exemplo, da integridade física e da filiação.
} 
sentido, a doutrina entende que, como as pessoas jurídicas tem por intuito a consecução de objetivos humanos, sendo, pois, dotadas de personalidades próprias, acertou o legislador ao atribuir-lhes a proteção dos direitos da personalidade (PEREIRA, 2010, p. 291).

Neste sentido é a doutrina de Carlos Alberto Bittar, para quem os direitos da personalidade são "plenamente compatíveis com pessoas jurídicas, pois, como entes dotados de personalidade (...) fazem jus ao reconhecimento de atributos intrínsecos à sua essencialidade" (BITTAR, 1990, p. 13).

O Superior Tribunal de Justiça, inclusive, editou a Súmula $n^{\circ} 227$, em que reconheceu expressamente a possibilidade de as pessoas jurídicas sofrerem dano moral. Com isso, fixou-se entendimento de que a pessoa jurídica é titular de sua própria honra, devendo ser indenizada este direito seja abalado. A conclusão que decorre logicamente deste entendimento é de que a pessoa jurídica é titular de direitos da personalidade, vez que não é necessário que haja prejuízo material efetivo para que faça jus à reparação civil.

O entendimento paradigmático que ensejou a edição desta Súmula foi proferido no Recurso Especial 60033-2/MG, julgado pelo STJ no sentido de que o direito à honra divide-se em honra subjetiva, que consiste auto concepção que o sujeito tem, e honra objetiva, consistente na reputação do sujeito no âmbito social em que está inserido.

Neste sentido, a pessoa jurídica não tem "capacidade de sentir emoção e dor", não possuindo, portanto, honra subjetiva. Entretanto, detentora que é de personalidade próprio, sendo, pois, titular de direitos da personalidade, conta com reputação perante a sociedade, a qual deve ser respeitada e preservada, por mais que seu abalo não enseje danos comprovadamente materiais. Afinal, possui existência autônoma na sociedade e é por esta avaliada em relação a todos os seus atos.

Acerca da distinção entre honra objetiva e subjetiva, convém destacar posicionamento da Ministra Nancy Andrighi proferido no âmbito do Recurso Especial $\mathrm{n}^{\mathrm{o}} 270.730 / \mathrm{RJ}$, para quem a honra objetiva consiste na "opinião social, moral, profissional, religiosa que os outros têm do indivíduo, e, honra subjetiva, a opinião que o indivíduo tem de si próprio". Seria, é verdade, ilógico cogitar-se do sofrimento das pessoas jurídicas por danos 
morais sofridos: não há uma consciência racional a ser abalada. Sofrem, entretanto, os danos decorrentes da deterioração de sua fama ${ }^{4}$ perante a sociedade.

Note-se que não é necessário que tal deterioração enseje prejuízos econômicos às pessoas jurídicas para que estas vejam-se indenizadas. A mencionada Súmula $\mathrm{n}^{\mathrm{o}} 227$ do STJ reconheceu expressamente a possibilidade de sofrerem dano moral, consistente justamente naquele que causa a "privação ou diminuição daqueles bens que têm valor precípuo (...) [como] a integridade individual (...), a honra e os demais sagrados afetos", estando dividido em dano à "parte social do patrimônio moral (hora, reputação etc) e dano que molesta a parte afetiva do patrimônio moral" (CAHALI, 1998, p. 20).

Portanto, conclui-se que as pessoas jurídicas são titulares de direitos da personalidade, dentre os quais inclui-se o direito à honra objetiva, cuja ofensa enseja o pagamento a responsabilização civil de que a causar.

\section{O DIREITO DE RESPOSTA NA LEI FEDERAL No 13.188/2015: O CONFLITO COM O DIREITO À HONRA OBJETIVA}

Antes da edição da Lei Federal no 13.188/2015 - Lei do Direito de Resposta, o direito de resposta na legislação brasileira tinha embasamento no art. $5^{\circ}, \mathrm{V}$, da Constituição Federal. Foi o que garantiu o Supremo Tribunal Federal no âmbito do julgamento da Arguição de Descumprimento de Preceito Fundamental no 130, que determinou que a Lei Federal n 5.250/1967 não fora recepcionada pela Constituição Federal.

Esta lei, denominada Lei de Imprensa, fora editada no contexto da Ditadura Militar e contava com caráter autoritário quanto ao controle da mídia pelos órgãos governamentais. O intuito do Supremo Tribunal Federal ao proferir tal decisão foi de resguardar a liberdade de expressão, já que a livre manifestação de pensamento consiste em direito fundamental consagrado pelo art. $5^{\circ}$, XIV, da Constituição Federal, sendo também essencial para o pleno desenvolvimento da democracia.

Ao tratar sobre o tema, o Superior Tribunal de Justiça, quando o julgamento do Recurso Especial n 680.794/PR, relatado pelo Ministro Luis Felipe Salomão, entendeu

\footnotetext{
${ }^{4}$ Apesar de recorrente na doutrina e na jurisprudência, seria atécnico utilizar-se a expressão "deterioração da imagem" para fazer referência a danos causados à honra das pessoas jurídicas, haja vista serem direitos autônomos.
} 
que a liberdade de expressão, ao ser exercida pela imprensa, possui viés duplo, decorrendo tanto do direito de informar como do de ser informado. Assim, caberia à imprensa o papel de "difundir conhecimento, disseminar cultura, iluminar consciências, canalizar as aspirações e os anseios populares, enfim, orientar a opinião pública no sentido do bem e da verdade”.

Não obstante este intuito, tal lei também determinava que, caso a honra ou a imagem de terceiros sofressem danos em razão de notícias divulgadas com desvio de sua finalidade informativa, tal terceiro poderia pleitear direito de resposta. Além disso, a Lei de Imprensa também determinava o procedimento e a abrangência do direito de resposta, traçando todo o procedimento que deveria ser utilizado por quem sofresse danos de ordem moral em razão de notícias divulgadas com o intuito de denegrir sua honra e imagem.

Assim, o julgamento da $\mathrm{ADPF} \mathrm{n}^{\circ} 130$, por mais necessário que fosse extirpar do ordenamento jurídico lei que limitasse de forma injustificada a liberdade de expressão teve este efeito negativo: extirpou também o mecanismo de defesa contra notícias abusivas.

O embasamento meramente constitucional, por mais que seja efetivo o argumento de que o direito de resposta decorre de princípios constitucionais e direitos fundamentais, pecava por não delinear o procedimento que deveria ser adotado para se fazer uso do direito de resposta. Assim, o ordenamento jurídico pátrio contava com lacuna procedimental que limitava o exercício do direito em questão.

Com o intuito de suprir esta omissão, foi editada a Lei de Direito de Resposta, cujo art. $2^{\circ}$ determina que "Ao ofendido em matéria divulgada, publicada ou transmitida por veículo de comunicação social é assegurado o direito de resposta ou retificação, gratuito e proporcional ao agravo".

$\mathrm{O} \S 1^{\mathrm{o}}$ do referido artigo complementa seu sentido, determinando que considera-se como ofensiva a matéria ou notícia que "atente (...) contra a honra, a intimidade, a reputação, o conceito, o nome, a marca ou a imagem de pessoa física ou jurídica". Vê-se, portanto, que as lesões que podem ensejar o exercício de tal direito são de ordem moral ou material, causadas a pessoas físicas ou jurídicas. 
Além disso, referida lei também delineou os procedimentos e prazos para exercício do direito de resposta, estabelecendo meios aptos a permitir que os indivíduos que se vejam abalados por notícias jornalísticas possam resguardar seus direitos e interesses.

O direito de resposta, doutrinariamente, pode ser definido como o desagravo promovido pelo sujeito em face de lesões a sua imagem ou a sua honra, somado à "reparação por danos morais e patrimoniais decorrentes do exercício impróprio da liberdade de expressão" (MENDES, 2008, p. 363). Com isso, vê-se que a liberdade de expressão, apesar de essencial em uma democracia, não é um direito absoluto.

A própria Constituição Federal, cujos incisos IV e XIV do art. $5^{\circ}$ consagram o direito de liberdade de manifestação de pensamento e de acesso à informação, determina, no inciso $\mathrm{X}$ do mesmo artigo, que tais liberdades não podem implicar em violação, dentre outros, à honra das pessoas. Há no caso, portanto, um conflito de direitos fundamentais: de um lado a liberdade de expressão, do outro, o direito à honra.

A liberdade de expressão, como já dito, possui duplo viés quando exercida pela imprensa: o direito de informar e o de ser informado. Não obstante sua importância, não é incomum que o direito à liberdade de expressão seja exercido de forma abusiva, mediante a veiculação, por exemplo, de notícia notoriamente inverídicas, com manipulação desleal de fatos e divulgação de suspeitas com base em prova alguma.

Neste sentido, se é vedado ao Estado prezar pela liberdade de expressão, não exercendo juízos prévios de censura, também é medida que se impõe a proteção dos direitos violados pelo exercício abusivo da liberdade de expressão. Convém, entretanto, ressaltar que a imprensa possui papel precípuo em democracias, pois disponibiliza aos cidadãos as informações necessárias para que estes, conscientemente, exerçam seus direitos democráticos. A imprensa é um dos "pilares do Estado Democrático de Direito", pois a democracia somente é efetiva caso os direitos garantidos sejam exercidos após o acesso às informações pertinentes.

Segundo o Ministro Celso de Mello, em decisão proferida em sede da Petição ao STF no 3.486-4/DF, dada sua importância, a liberdade de expressão concede ao jornalista "o direito de expender crítica, ainda que desfavorável e exposta em tom contundente e sarcástico, contra quaisquer pessoas ou autoridades.”. Portanto, a publicação de notícia 
jornalística, "por mais dura que seja", não restará eivada de abuso de direito caso tenha intuito informativo, e não difamatório, e tenha base em fatos (pelo menos) plausíveis.

Ainda segundo o Ministro Celso de Mello, "a crítica jornalística, quando inspirada pelo interesse público (...) não traduz nem se reduz, em sua expressão concreta, à dimensão do abuso da liberdade de imprensa". Assim, tais manifestações não estão passíveis de sofrer qualquer "restrição estatal", de qualquer ordem que seja.

Conclui-se, portanto, que o exercício de liberdade de expressão, desde que tenha intuito informativo, e não difamatório, baseando-se no interesse e no direito público de acesso à informação, e desde que tenha fundamentação plausível deve prevalecer sobre eventual prejuízo causado à honra objetiva, pois consiste em regular exercício de direito. ${ }^{5}$

Convém, portanto, analisar esta conclusão sob o espectro do Direito Civil, pois o direito de resposta possui natureza civil de obrigação de fazer, estando, pois, inserido no âmbito da responsabilidade civil. O art. 187 do Código Civil define como ato ilícito o exercido fora dos limites impostos por lei. Assim, somente seria aceita pretensão indenizatória em face do exercício do direito de expressão caso houvesse excesso. Não sendo o caso, inexiste ato ilícito, inexistindo, também, pretensão indenizatória e de imposição de obrigação de fazer.

Portanto, a liberdade de expressão exercida nos termos acima descritos revela-se como exercício lícito de um direito, que inclusive tem natureza de direito fundamental. Assim, não se asseverando o cometimento de ato ilícito, revela-se incabível a

\footnotetext{
${ }^{5}$ Apesar de não estar no escopo deste trabalho, dada a limitação metodológica adotada, convém destacar de que nosso posicionamento é de que o correto exercício do direito de imprensa também não implica em violação aos demais direitos das pessoas jurídicas resguardados pelo $\S 1^{\circ}$ do art. $2^{\circ}$ da Lei de Direito de Resposta. Isto se dá, em breves linhas, que pretendemos desenvolver em trabalho posterior sobre o tema, porque: (i) as pessoas jurídicas não contam com direito à intimidade, sendo este exclusivo das pessoas naturais; (ii) a reputação de que trata o legislador confunde-se com a honra objetiva, mantendo-se os argumentos esposados neste trabalho; (iii) o "conceito" consiste em termo abstrato utilizado, a nosso ver, de forma equivocada pelo legislador, que, tentando estender a aplicabilidade do direito de resposta, utilizou termo completamente indefinido, não havendo bem jurídico a ser tutelado; (iv) o nome das pessoas jurídicas consiste na firma ou denominação social, conforme determinação do art. 1.155 do Código Civil, cuja proteção, restringe-se à vedação do registro de nome idêntico e da utilização para fins comerciais, sendo lícita a menção ao nome como forma de identificação da pessoa jurídica para referir-se a ela em notícia jornalística; e (v) considera-se violada uma marca em razão de sua utilização para fins comerciais por quem não seja seu titular, conforme determinado pelo art. 129, 183, 190 e 195, incisos III a XIV, da Lei Federal no 9.729/1996, bem como pela publicação de falsa informação acerca de marca com o intuito de se obter vantagem ilícita, nos termos dos incisos I e II do art. 195 da mencionada lei, de modo que a mera referência a uma marca em notícia jornalística não implica em violação de direito do seu detentor.
} 
imposição ao meio de comunicação de dever de conceder direito de resposta àquele sobre quem se publicou notícia de suspeita de envolvimento em caso de corrupção.

\section{A DIVULGAÇÃo DE NOTÍCIAS SOBRE SUPOSTO ENVOLVIMENTO DE PESSOAS JURÍDICAS EM CASOS DE CORRUPÇÃO}

Recentemente, tem-se tornado comum a divulgação de notícias sobre suspeitas de envolvimento de pessoas jurídicas em esquemas de corrupção. Diz-se que tais casos são de suspeita de envolvimento porque, em um Estado Democrático de Direito, conforme expressa disposição do art. 5 , LVII, da Constituição Federal, a inocência presumese até o trânsito em julgado de sentença condenatória.

Portanto, toda e qualquer notícia divulgada antes de ser proferida decisão judicial definitiva retrata uma suspeita, pouco importando que os indícios apresentados pelas autoridades competentes pela investigação sejam interpretados como inquestionáveis.

Convém abrir breve parêntese para informar que tanto notícias que identifiquem a pessoa jurídica como envolvida como aqueles que indiquem como autores seus dirigentes e representantes incluem-se no assunto ora tratado. Isto se dá porque o já mencionado art. $2^{\circ}$ da Lei Federal $n^{\circ} 12.846 / 2013$ determina que as pessoas jurídicas são objetivamente responsáveis pelos atos praticados em seu interesse ou benefício.

Assim sendo, ao ter ato de corrupção praticado em seu favor, seja mediante o ganho de lucros indevidos, seja pela diminuição da competição ou da combinação de preço para participação em certames licitatórios, a pessoa jurídica de direito privado deve ser responsabilizada, conforme expressa previsão legal. ${ }^{6}$

A imprensa, como já dito, tem papel precípuo na divulgação de informações, utilizando-se da abrangência de sua circulação para informar o maior número de pessoas possíveis, papel este essencial ao Estado Democrático de Direito. Não obstante, o direito de liberdade de expressão deve ser exercido de forma responsável, sem abuso de prerrogativas.

\footnotetext{
${ }^{6}$ Convém destacar que esta determinação legal decorre do fato de que o intuito da lei em comento é, dentre outros, o de tornar viável e atrativo às pessoas jurídicas de direito privado a adoção de medidas com o intuito de prevenir a prática destes atos.
} 
Portanto, para que o direito de resposta não possa ser exercido em face de notícias jornalísticas, é necessário que estas tenham por base indícios ao menos plausíveis, devendo também ser feitas as devidas ressalvas quanto ao fato em questão é uma suspeita de envolvimento, sob investigação ou julgamento.

Caso esta cautela não seja adotada, mesmo que indiretamente, no corpo do texto e não em seu título, restará configurado o desvio de finalidade da notícia, que retratará como definitivo o entendimento de que houve envolvimento de tal pessoa jurídica, juízo este que cabe exclusivamente ao Poder Judiciário.

Quanto à questão das provas, é plausível a conclusão de que, havendo investigações oficiais, denúncias do Ministério Público e processos administrativos ou judiciais em andamento, há indícios suficientes que embasem a divulgação de notícias de suspeita do cometimento de atos de corrupção nos casos em questão.

Da mesma forma, há de se concluir pela existência de interesse público no conhecimento de tais notícias, pois os fatos de que tratam tais denúncias referem-se ao patrimônio público. É parte do precípuo papel da imprensa divulgar desmandos e desvios realizados com o patrimônio que, ao menos em tese, pertence à coletividade.

Não há dúvidas de que a divulgação da suspeita de envolvimento de pessoas jurídicas em escândalos de corrupção é prejudicial à sua honra objetiva, pois levará a sociedade em que está inserida a duvidar da licitude e da ética de sua atuação.

Conforme já tratado, a divulgação da prática de atos de corrupção implica em uma ruptura de uma relação de confiança e da convivencialidade entre o indivíduo que praticou o ato e aquele que foi lesado, pois as normas jurídicas que previnem este tipo de ato e servem justamente para manter a boa convivência social terão sido violadas.

Não obstante, mesmo considerando este dano, vê-se que ele não decorre de um ato ilícito, mas, pelo contrário, do exercício de um direito fundamental, essencial para o Estado Democrático de Direito, que é a liberdade de expressão. Assim sendo, o melhor posicionamento a ser adotado não é o que implica em punição, consistente na imposição de uma obrigação de fazer, em decorrência do correto exercício de um direito. 
Por mais que o direito de personalidade à honra reste prejudicado pela divulgação de notícias nos termos ora tratados, não se vê ilicitude neste prejuízo: será ele devido ou provisório, conforme seja ou não proferida decisão condenatória. Em sendo proferida sentença condenatória, restará comprovado que a imprensa cumpriu corretamente seu papel e informou a população acerca de atos ilícitos praticados com recursos públicos.

Caso, por outro lado, a sentença seja de improcedência, ainda assim não se pode concluir que os meios de comunicação terão agido com excesso, pois terão levado a conhecimento público apenas a existência de averiguações ou procedimento acerca de tais atos. $^{7}$ Neste caso, por mais que a pessoa jurídica em questão seja considerada inocente, é direito dos cidadãos tomar conhecimento acerca de suspeitas fundadas da prática de atos ilícitos envolvendo o erário público.

Entretanto, isso não decorre só do interesse que existe pela coisa pública em geral: é concebível que a pressão popular evite que procedimentos investigatórios ou judiciais sofram ingerências de interesses escusos, propícios à não punição de ilícitos.

Neste caso, entretanto, faz parte do lícito exercício da liberdade de expressão a divulgação do inocentamento da pessoa jurídica em questão, o que se justifica por dois motivos. O primeiro é que, da mesma forma que os cidadãos têm interesse em tomar conhecimento de indícios de autoria e materialidade de ilícitos envolvendo bens públicos, também é de seu interesse aferir tais recursos estão, na verdade, sendo utilizados licitamente.

Além disso, o papel da imprensa não é somente o de incitar curiosidade acerca de fatos cuja apuração não foi finalizada, prática esta semelhante ao sensacionalismo midiático, mas sim o de levar a conhecimento dos cidadãos fatos que lhes permitam exercer corretamente seus direitos e deveres.

Desta forma, conclui-se que a divulgação de notícias jornalísticas que retratem suspeitas de envolvimento de pessoas jurídicas em caso de corrupção não ensejam a

\footnotetext{
${ }^{7}$ Convém destacar que o art. $3^{\circ}$ da Lei do Direito de Resposta estipula prazo decadencial de 60 (sessenta) dias a contar da data de divulgação da notícia contra a qual se pretende exercer direito de resposta para que o indivíduo prejudicado notifique o veículo de comunicação social acerca de seu intuito de exercer tal direito. Portanto, é necessário que haja construção legal, jurisprudencial ou doutrinária acerca do exercício de tal direito em casos em que o veículo de comunicação social exerce regularmente seu direito ao divulgar suspeita de envolvimento de pessoa jurídica em caso de corrupção.
} 
responsabilização civil do meio de comunicação social, não the podendo ser imposta obrigação de fazer consistente na concessão de direito de resposta.

\section{CONCLUSÃO}

Diante do exposto, conclui-se, inicialmente, que as pessoas jurídicas de direito privado, constituídas mediante expressão volitiva de vontade de indivíduos para a persecução de seus interesses, possui personalidade própria, cabendo-lhes, na medida do possível, a proteção decorrente dos direito da personalidade.

Dente os direitos da personalidade garantidos às pessoas jurídicas, destacase o da honra objetiva, que consiste no juízo ético de valor que a sociedade tem da pessoa jurídica, havendo o Poder Judiciáio reconhecido que não é necessário que haja dano patrimonial a pessoa jurídica decorrente de fato ilícito para o causador do dano ser devidamente responsabilizado.

Além disso, chegou-se à conclusão de que, não obstante as consequência gravosas à honra das pessoas jurídicas em razão da divulgação de suspeitas de seu envolvimento em casos de corrupção, considerando que tal divulgação decorre de exercício de direito a liberdade de expressão, não se vê como possível a responsabilização civil de quem tenha realizado tal divulgação. Afinal, a imprensa tem papel de suma importância em democracias.

Para tanto, não obstante, é necessário que o direito de liberdade de expressão seja executado com parcimônia e responsabilidade, sempre indicando tratar-se apenas de suspeita de envolvimento e baseando-se em fatos e indícios que também estejam sendo analisados pelos órgãos do Poder Público competentes para este intuito.

Portanto, sendo o direito de expressão exercido com observância aos limites legais, não restará configurado ato ilícito, mas exercício lícito de um direito de natureza fundamental, não fazendo, pois, a pessoa jurídica cujo envolvimento tenha sido reportado jus a utilizar-se de direito de resposta, estipulado nos termos da Lei de Direito de Resposta.

\section{Referências bibliográficas}


ADPF no 130. Disponível em <

http://redir.stf.jus.br/paginadorpub/paginador.jsp?docTP=AC\&docID=605411 $>$. Acesso em 01 de julho de 2016, às 14:00.

BARROS FILHO, Clóvis de; PRAÇA, Sérgio. Corrupção: parceria degenerativa. Campinas/SP: Papirus 7 Mares, 2014.

BEVILÁQUA, Clóvis. Teoria Geral do Direito Civil. Rio de Janeiro: Livraria Francisco Alves, 1908.

BITTAR, Carlos Alberto. Os Direitos da Personalidade. $2^{\mathrm{a}}$ ed. Rio de Janeiro: Forense Universitária, 1995. 1990.

O direito civil na Constituição de 1988. São Paulo: Revista dos Tribunais,

BRASIL. Revogada Lei de Imprensa. Lei Federal no 5.250, de 9 de fevereiro de 1967. Regula a liberdade de manifestação do pensamento e de informação. Disponível em < http://www.planalto.gov.br/ccivil 03/leis/L5250.htm>. Acesso em 02 de julho de 2016, às 22:08.

Constituição Federal de 1988. Disponível em

<http://www.planalto.gov.br/ccivil 03/constituicao/constituicaocompilado.htm>. Acess o em 10 de julho de 2016, às 22:45.

Código Civil. Lei Federal no 10.406, de 10 de janeiro de 2002. Institui o Código Civil. Disponível em < http://www.planalto.gov.br/ccivil_03/leis/2002/110406.htm>. Acesso em 04 de julho de 2016, às 01:45.

Lei Anticorrupção. Lei Federal n ${ }^{\circ} 12.846$, de $1^{\circ}$ de agosto de 2013. Dispõe sobre a responsabilização administrativa e civil de pessoas jurídicas pela prática de atos contra a administração pública, nacional ou estrangeira, e dá outras providências.

Disponível em < http://www.planalto.gov.br/ccivil 03/ ato20112014/2013/lei/112846.htm>. Acesso em 03 de julho de 2016, às 23:49

Lei do Direito de Resposta. Lei Federal n ${ }^{\circ}$ 13.188, de 11 de novembro de 2013. Dispõe sobre o direito de resposta ou retificação do ofendido em matéria divulgada, publicada ou transmitida por veículo de comunicação social. Disponível em,$<$ http://www.planalto.gov.br/ccivil 03/ Ato2015-2018/2015/Lei/L13188.htm>. Acesso em 01 de julho de 2016, às 13:45.

CAHALI, Yusef Said. Dano Moral. $2^{a}$ Ed. São Paulo: Editora Revista dos Tribunais, 1998.

CARVALHOSA, Modesto. Considerações sobre a Lei Anticorrupção das Pessoas Jurídicas: Lei 12.846/2013. São Paulo: Editora Revista dos Tribunais, 2015. 
DONEDA, Danilo, "Os direitos da personalidade no Código Civil" in TEPEDINO, Gustavo. A Parte Geral do Novo Código Civil: estudos na perspectiva civilconstitucional. 2 ed. Rio de Janeiro: Renovar, 2003.

GLAESER, Edward. GOLDIN, Claudia. Corruption and Reform: An introduction. Disponível em: 〈http://www.nber.org/papers/w10775.pdf〉.

GOMES, Orlando. Introdução ao Direito Civil. 11 a ed. Rio de Janeiro: Editora Forense, 1996.

GONÇALVES, Carlos Roberto. Direito Civil Brasileiro, volume 1: parte geral. $11^{\mathrm{a}} \mathrm{ed}$. São Paulo: Saraiva, 2013.

LEAL, Leonardo José Peixoto. DA ROCHA, Maria Vital. Direitos da Personalidade e a Proteção do Conteúdo Patrimonial dos Direitos Autorais. Disponível em: http://www.publicadireito.com.br/artigos/?cod=cff815dabb3555cf. Acesso em 05 de julho de 2016, ás 03:50.

MENDES, Gilmar Ferreira. Curso de Direito Constitucional. 2. ed. São Paulo: Saraiva, 2008 ,

MENEZES, Joyceane Bezerra de. Notas sobre a natureza jurídica do embrião humano e o marco inicial dos direitos de personalidade. NOMOS: Revista do Programa de PósGraduação em Direito da UFC, Fortaleza, v.28, n.1, 2008, p.191-208.

MONTEIRO, Washington de Barros. Curso de Direito Civil: parte geral. 39a ed. São Paulo: Saraiva, 2003.

NUCCI. Guilherme de Souza. Corrupção e Anticorrupção. Rio de Janeiro: Forense, 2015.

PELUSO, Cezar. Pronunciamento na abertura do Fórum Internacional Liberdade de Imprensa e Poder Judiciário. Brasília, 27 de maio de 2011. Disponível em: $<$ http://migre.me/58SdF>. Acesso em 12 de julho de 2016, às 00:22.

PEREIRA, Caio Mário da Silva. Instituições de Direito Civil - V.1. Introdução ao direito civil: teoria geral do direito civil. Rio de Janeiro, Editora Forense, 2010.

RIZZARDO, Arnaldo. Parte Geral do Código Civil: Lei no 10.406, de 10.01.2002. Rio de Janeiro: Editora Forense, 2007. 